\title{
Central Place and Liminal Landscape in the Territory of Populonia
}

\author{
Giorgia Maria Francesca Di Paola 1,2 \\ 1 Department of Historical Science and Cultural heritage, University of Siena, Via Roma n. 56, \\ 53100 Siena, Italy; giorgiadipaola@hotmail.com \\ 2 Department of Humanistic Studies, University of Foggia, Via Arpi n. 176, 71121 Foggia, Italy
}

Received: 2 July 2018; Accepted: 29 July 2018; Published: 3 August 2018

\begin{abstract}
This article aims to outline new data on the urbanization of Populonia starting from its foundation, with particular reference to the results of archaeological surveys carried out by the University of Siena since the 1980s. The landscape archaeology approach has allowed us to reconstruct the Etruscan city's organization of settlements as well as its management of resources. In addition, this investigative tool has proven the most effective method to detect both places of economic or ideological centrality and specific liminal landscapes in the territory of Populonia. The urban development of the Etruscan city represents an anomalous case for several reasons that are mainly dependent on its shape, which required unconventional choices in the organization and management of its territory and natural resources. Our research leads us to suggest that the Etruscan city's acropolis seems to have played the role of central place starting right from the establishment of the city. Within some of the new acquisitions coming from my PhD research we have to consider the feature of the hilltop fortresses system and the detection of a "liminal landscape" in the northeastern stretch of the territory between Populonia and Volterra. This particular part of the landscape had been a sacred district with a strong peripheral character and possibly close connections to the central place thanks to the significant availability of natural resources.
\end{abstract}

Keywords: landscape archaeology; Populonia; settlement organization; supply basin; central place; hilltop fortresses; liminal landscape; connectivity; viewshed analysis; sacred areas

\section{Introduction}

This paper aims to outline some of the most important phases of Populonia's urban development starting from its foundation, with particular reference to the results of archaeological surveys carried out by the University of Siena since the 1980s. My new data on the urbanization of Populonia is one of the most significant results of my PhD research project focused on the development of the Populonia frontier and territory with respect to the neighboring Etruscan centers of Volterra to the north, and Vetulonia and Roselle to the south. To pursue this goal, I reconstructed both the organization of the settlements and the management system of resources applied by Populonia on the longue durée, moving from the Late Bronze-Early Iron Age to the Hellenistic period. In this paper, I concentrate on the period between the 6th century BC to the 3rd century BC, before Populonia was incorporated into the Roman Empire.

From this point of view, my PhD research could be included in the general branch of knowledge concerning the definition of the political and ethnic frontiers between one or more communities. Although the human need to establish cultural-group borders already existed long before, it was only starting from the end of the 19th century that the frontier became a subject of study. Some scholars investigated this field by making historical border reconstructions, within the context of military interests of colonialism and nationalism politics [1] (p. 23). F. J. Turner, on the contrary, studying 
the frontier in American history, interpreted it entirely as free lands to colonize, taking no interest in indigenous people living there [2]. From the 1950s, when most European colonies gained their independence, some scholars, such as Owen Lattimore, considered the frontier as the area of interaction between people from different cultures [3]. The scientific debate of the 1970s saw the predominance of both the core-periphery model and the emergence of the world system theory [4], well-suited to explain the hierarchical organizations of trade connections in the world. In terms of archaeological perspective, this system was the first theoretical model that tried to explain the influence of the contacts between different communities on promoting cultural changes in specific ethnic groups [5-7]. During the last two decades of the 20th century, some areas of research highlighted an idea of the frontier as a permeable meeting zone and cultural exchange area depending both on the flexibility of the political authority and the elasticity of its territorial control $[8,9]$.

Although political frontiers can be considered some of the most visible evidence of ethnic identity in pre-Roman central Italy, my study specifically deals with political frontiers on the sub-regional level [10]. As G. Cifani, L. Ceccarelli and S. Stoddart note, "In pre-Roman Etruria, as a general rule, we can say that frontiers take a number of forms depending on the configuration of the power centers, the physical circumscription of the area and the topography of the landscape" [10] (p. 164).

The need to study and define the territorial limits of specific communities requires the interaction with other scientific approaches, such as spatial archeology and landscape archaeology, specifically to understand the ways in which people in the past constructed and used the environment around them. The first approach encourages the application of both modern geographic-economic models and statistics to archaeological evidence in order to interpret site distributions in the landscape [11] (p. 9). Among the most interesting interpretative models, we have to mention: (1) the Early State Module, applied at first to Mycenaean Greece state societies, then to Etruscan cities [12] (pp. 3-59); this method was recently implemented by the XTENT model that permits variations in the size of territory, also evaluating the "friction" of the physiography of the landscape [13]; (2) the Thiessen Polygon Method, to describe settlement patterns based on territorial divisions centered on a single site or feature; (3) the peer polity interaction to explain change in society and in material culture [14]. A recent update is also the landscapes of power theory that aims to develop analytical models to simulate and study political arrangements of ancient territories. This approach intersects various disciplines, such as social archaeology, anthropology and geography [15-17].

Landscape archaeology is an area of study that surpasses the conventional boundaries between disciplines and provides a fresh perspective and a powerful investigative tool to address research questions related to the conscious and the unconscious shaping of the land and the process of organizing space, involving interactions between the physical environment and human presence.

Landscape is never inert: people are directly associated with it, rework it, appropriate it and contextualize it [18] (p. 3). As Ashmore notes, "prominent among the meaning of landscape are power and identity, variously defined and expressed in sundry forms" [19]. As landscape delineates memory and declares identity, the land itself plays a fundamental role in social-cultural order and in human relationship [20]. Furthermore, "as a community merges with its habitus through the actions and activities of its members, the landscape may become a key reference point for expressions of individual, as well as group, identity" [21].

Thus, the methodological approach chosen to carry out the detection of Populonia frontiers and the development of its territory was basically multidisciplinary and it derived from: (1) a detailed collection of records and knowledge coming from different sources, such as archive documents, historical and epigraphic sources, as well as archeological and geological data; and (2) the setting-up of a specific geographic information system, capable of storing, managing and analyzing the different kinds of data and displaying them on a map.

Since the 1980s, thanks to the results from archaeological surveys carried out by the University of Siena, research on the territorial organization of Populonia has improved and the landscape archaeology approach, as a whole, has shown itself to be the most effective method of identifying the 
structural context of Populonia (Figure 1). The detection of a specific liminal landscape as well as the feature of the hierarchical fortified system are some of the new data coming from my PhD research. They also contribute to recognize Populonia's places of economic or ideological centrality as well as to re-evaluate "marginal landscapes" in the surrounding territory.

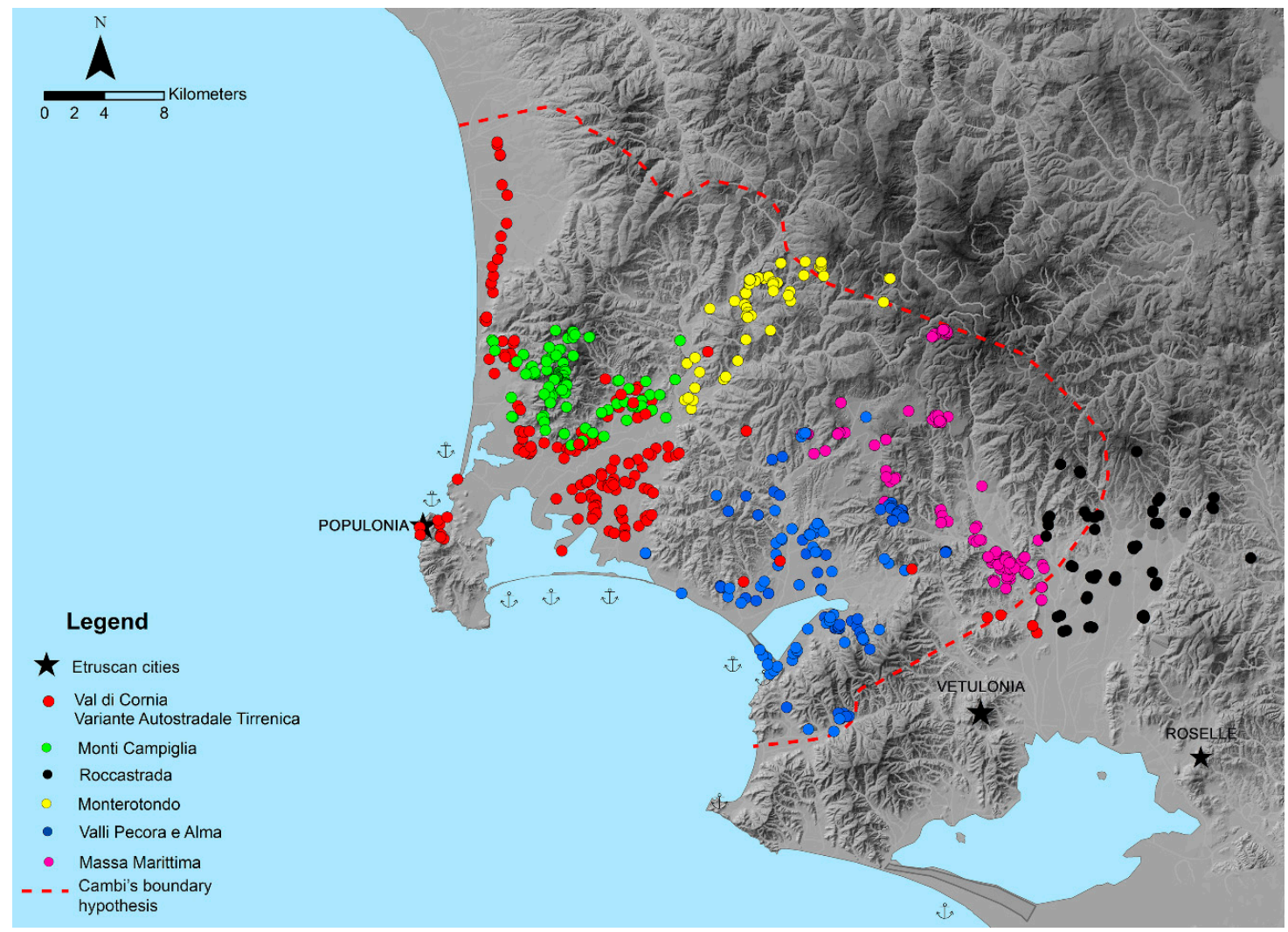

Figure 1. General map of archaeological surveys in the territory of Populonia undertaken by the University of Siena since 1980s.

\section{The Birth of Populonia in the Early Iron Age and its Urban Development}

The urban development of Populonia represents an anomalous case for several reasons that are mainly dependent on its shape, which required unconventional choices in the organization and management of its territory and natural resources [22] (Figure 2).

Firstly, Populonia was the only Etruscan city that was directly on the coast. It occupied the hills of Poggio del Telegrafo and Poggio del Castello and overlooked the Gulf of Baratti. During the 5th century $\mathrm{BC}$, when the territory of Populonia reached its maximum expansion, it stretched approximately from Donoratico to the north and the Alma river to the south of the Piombino headland [23]. In ancient times the landscape was very different: there were many coastal lagoons that, particularly in the Piombino area, made the headland into a particular kind of peninsula [24,25]. The Populonia surrounding was highly varied: it was characterized by a succession of hills and flat lands, by the presence of hot sulphur springs and was traversed by many rivers. Thus, the city benefited from a territory with great potential, rich in natural resources. The coastal lagoons served numerous functions: they supplied fundamental food resources, for instance, here fish were farmed and salt produced; they provided harbors for medium-size boats; they served as protective-climate areas during winter grazing along the transhumance routes and during cultivation cycles of grain and trees [26,27]. In addition to this formidable food supply, Populonia could draw on other resources in the form of mixed sulphides and iron ore extracted from the quarry of the Campigliese district and the Island of Elba, as well as the Buca delle Fate site. 


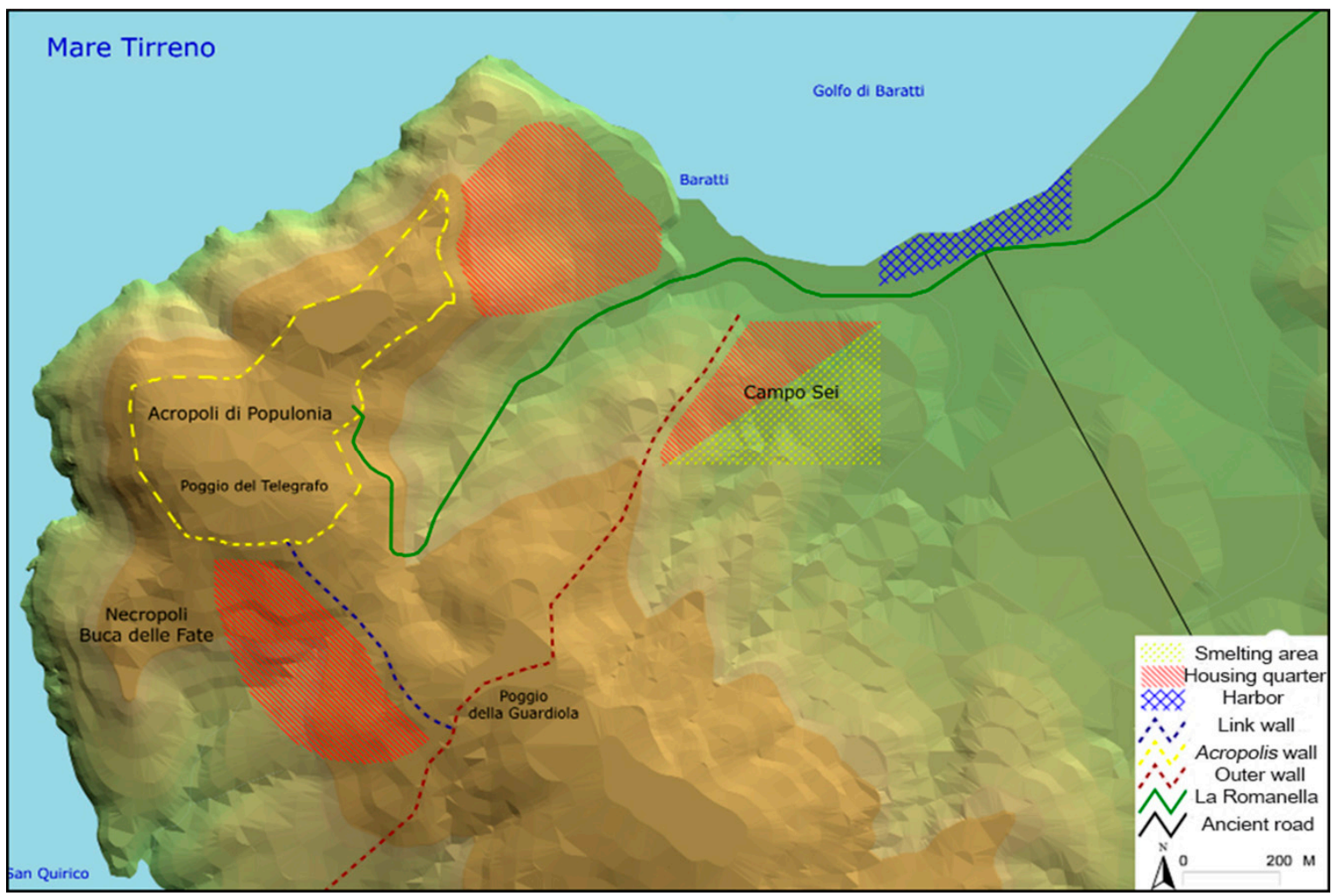

Figure 2. Populonia: the acropolis site. The Early Iron Age Poggio del Telegrafo settlement.

Secondly, there are not many literary sources about Populonia, but one of the most interesting legendary traditions is referred to by the Late Antiquity writer Servius, who indicated Populonia as the last city founded among the Etruscan centers; he also suggested three possible provenences of the founders: as settlers from Corsica, or from Volterra, or as a group that forced out a previous community. Although this source is not easily verified, the hypothesis of a close relationship between the Island of Corsica and Populonia might be deduced from the analogies of specific material culture and funerary practices during the 9 th and the 8 th century BC [28]. It is significant that the same analogies can also be identified in the Iron Age material culture, including both imported and imitation goods [29] as well as funerary practices from Sardinia and the Island of Elba. Some rituals present here have been directly attributed to Sardinian and Corsican influences: for instance, the early adoption of burial rituals and the practice of burying a group of people in caverns or natural clefts spread throughout the Island of Elba and is well attested in the Riparo Biserno site (San Vincenzo-Livorno). A high level of connectivity must have linked these local communities. Thus, it is likely that the maritime trades in this part of the Tyrrhenian Sea were controlled by clan families who lived in Populonia, and on the Islands of Elba, Corsica and Sardinia. The situation could also be proved by the lack of material culture coming from areas external to this specific trade network [30]. In the late Iron Age, Vetulonia took part in this trade network, too and it seemed to be in competition with Populonia [31] (p. 286). The Island of Elba, in all probability, was included in the Populonia dominions at least from the Early Iron Age, if not before [32]. The Villanovan Populonia appears to be the hub of a geographical district rich in resources and not only as a crucial junction of Tyrrhenian passage but also of the main Mediterranean routes [22].

Thirdly, the growth of Populonia seems to differ slightly from the "city-territory" model, or urbs-ager, based on the city's prevalent role over its countryside. Populonia appears closer to the example of some Magna Grecia colonies' territorial evolutions, such as Metaponto [33], characterized by a strong dualism of the political center on the acropolis and the surrounding lands. This duality is highlighted by the analysis of the relationship that the city established with its supply basin [26] 
(p. 73). In the Late Bronze Age, the top of the Piombino headland was unpopulated. By contrast, many small settlements appeared along the coastline and in the Campigliese district. Based on our current knowledge, the biggest coastal settlement was located on Poggio del Molino: we can probably link the Villa del Barone necropolis to this site, which was found less than $500 \mathrm{~m}$ away [34]. Revealed through chance archaeological finds, the other coastal sites-Villa Salus [35], Riva degli Etruschi [36] (pp. 123-124), La Torraccia [36] (p. 125), Centro Velico/Casone [37] and Torre Mozza [36] (pp. 125-126) — could be interpreted as small specialized manufacturing settlements. The only site we can be sure of, in terms of its kind of manufacturing activities, is the Centro Velico/Casone site where salt was extracted [31]. In the Campigliese district, rich in mixed sulfides and iron ore, the sites had the specific function of controlling mining activity: a clear example is the Vallin del Mandorlo settlement [38] (Figure 3).

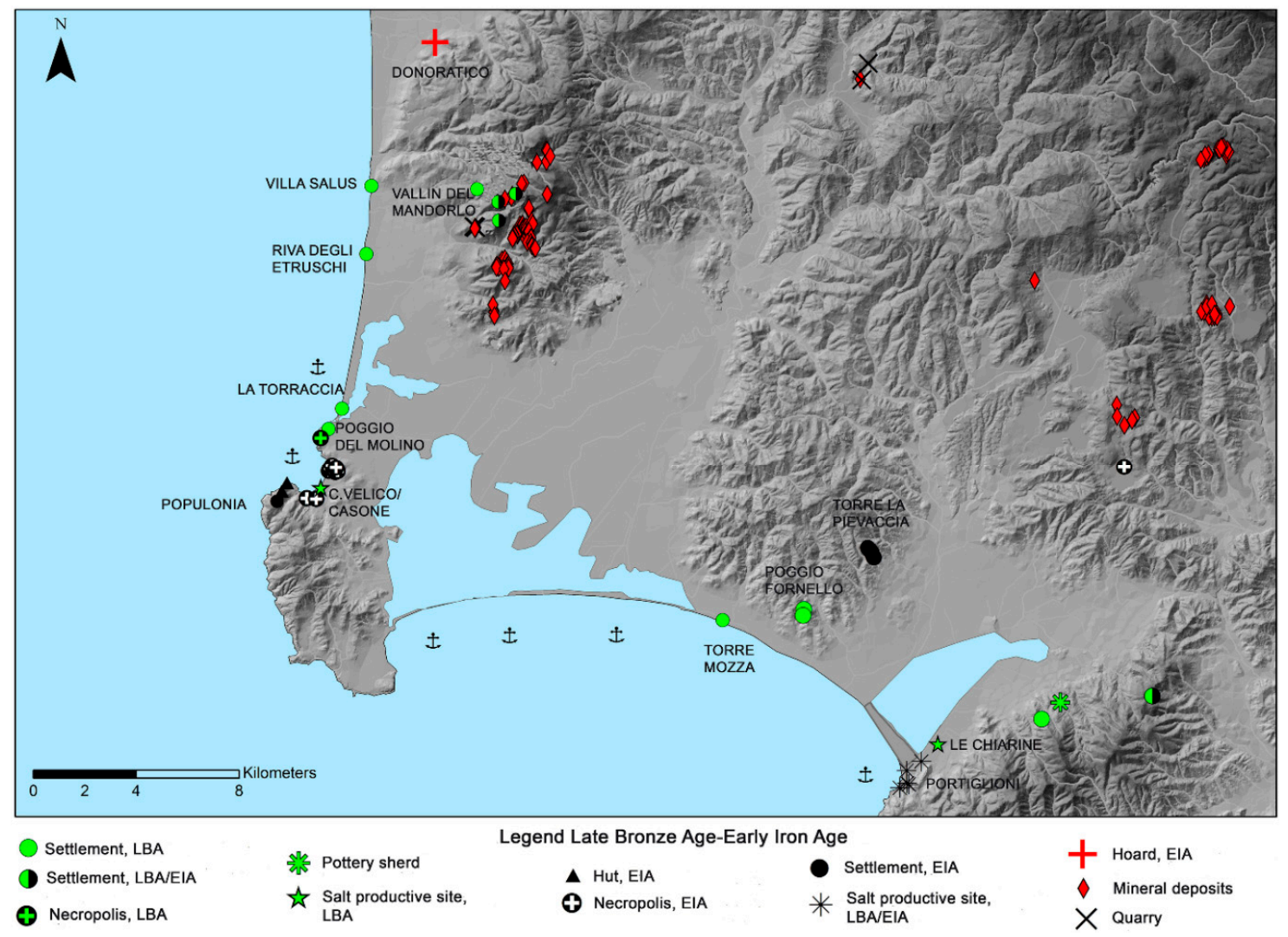

Figure 3. GIS general map of Populonia's settlement distribution during the Late Bronze Age and the Early Iron Age.

In the Early Iron Age, the area of the historical city, corresponding to Poggio del Telegrafo and Poggio del Castello, was populated by a community with evident status markers and segmented into family clans, as archaeological data suggest [39]. This site was chosen because of its dominant and naturally defensible position overlooking neighboring territory, the port, the Gulf of Baratti as well as the ancient coastal lagoons and the Island of Elba and, with good weather conditions, the Island of Capraia and Cape Corse [40]. The time period of the city's early development seems to correspond to the abandonment of the Late Bronze Age settlements along the coastline. Although archaeological evidence is lacking, some argument for this interpretation can be made at least for the Gulf of Baratti area, where the necropolis overlaps the previous settlement. It is possible to relate this phenomenon to the simultaneous concentration of the population in the historical city area, as part of a larger commitment to planning, which also involved the gulf [22] (p. 61). The arrangement of the Early Iron Age necropolis was anomalous in comparison with other Etruscan cities, such as 
Veio, Tarquinia, Cerveteri and Vulci, where the funerary areas entirely enclosed the settlements [41] (p. 105). Because of the particular shape of the ancient coastal landscape, the necropoli were laid out on the most unencumbered areas facing the Gulf of Baratti and thus Populonia was surrounded by them [22] (pp. 66-68). While the proto-historic settlements were almost completely abandoned, the small Campigliese sites persisted and controlled mining activities [42], establishing the great dualism between the acropolis site and the resources of the neighboring countryside. It is not always clear whether the urban acropolis site was more influential on the chora, endowed with a variegated supply basin, or if the opposite [26] (pp. 73-74) was true. In spite of sparse archaeological data after its establishment, Populonia promoted a hierarchical settlement system, centered on a network of sites and on the foundation of new population centers, in keeping with most of the Southern Etruscan cities. In this respect, the common burial ground at the Riparo Biserno site (Livorno) and the Monte Pitti necropolis are particularly relevant during the Iron Age. The first, joined with the archaeological evidence from the small Campigliese sites, proves the existence of a network of minor settlements in charge of mining activities [22] (Figure 4). Even without knowing which settlements were tied to the Monte Pitti burial ground, we can still presume that it had been sited in a strategic position, probably to control access to the Campigliese mineral basin. All of these evidence-based considerations lead us to presume that, starting from the Early Iron Age, the acropolis settlement can be considered the central place: the community living there represented a catalyst for employing resources from both the Campigliese district and the surrounding supply basins.

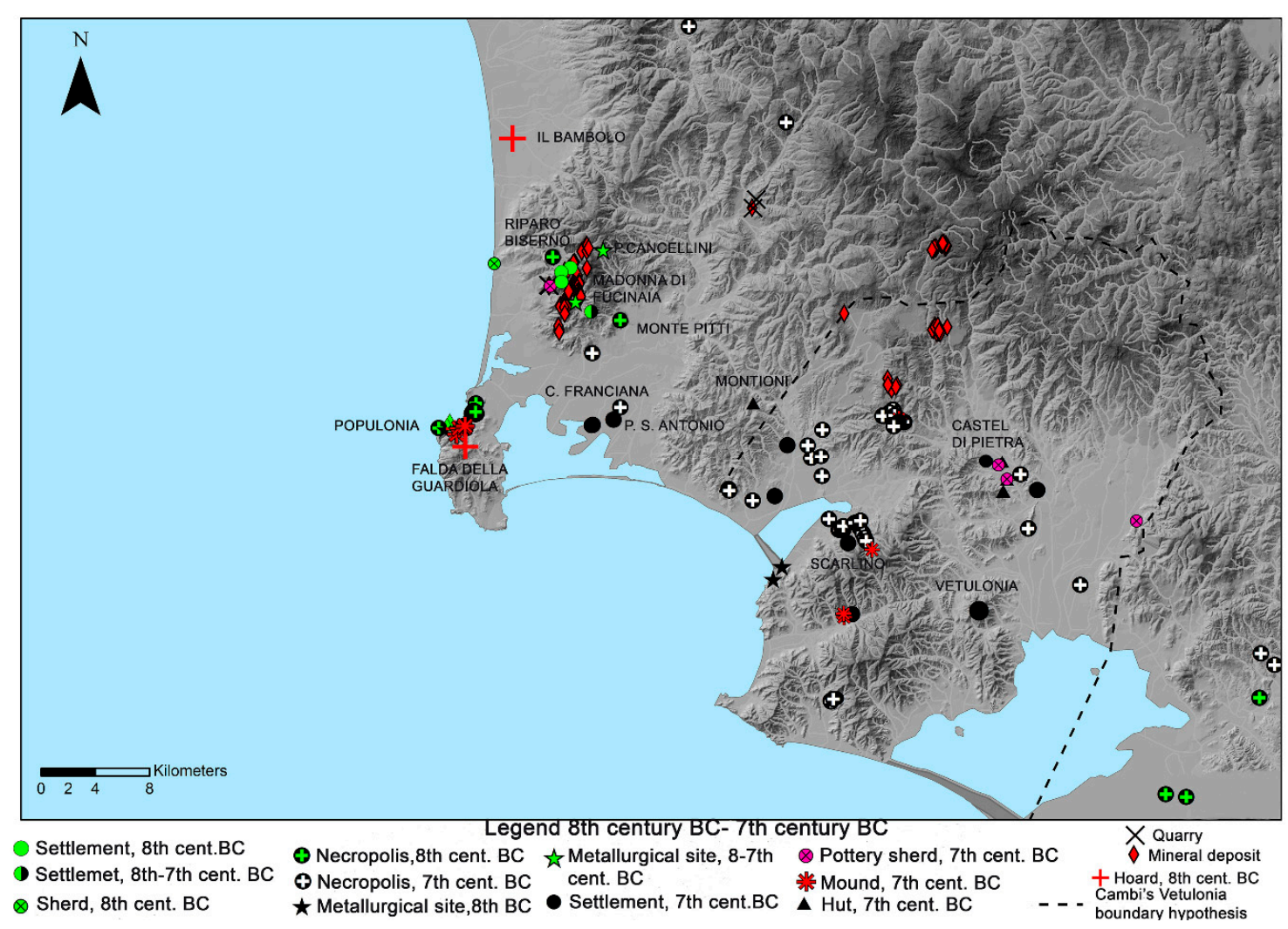

Figure 4. GIS general map of Populonia's settlement distribution during the end of the 9th/the beginning of the 8 th century BC and the first half of the 7th century BC.

\section{From the Archaic Period to the Hellenistic Period}

In the 6th century BC, two important events occurred in Populonia: (1) dwellings disappeared in the acropolis area, probably connected with a change in the social and economic order. From this period onward, in fact, the acropolis seems to have been used as the ritual core of the town [39]; 
(2) the beginning of intensive metallurgical activities in the lower town, in particular on the slopes of Poggio della Guardiola and Poggio della Porcareccia, especially from the end of the 6th century $\mathrm{BC}$ [43]. This phenomenon suggests a radical change in the social order, which had to adapt aristocratic assets to the needs of a dynamic system, marked by the emergence of a new middle-class employed in intensive iron smelting operations [44]. This development is well-documented by the funerary evidence and the inscriptions, nevertheless other important changes followed during the same period.

First, Populonia laid out some sacred sites to mark the transition with its suburban areas and its countryside (ager) [45,46]. Second, the Campigliese district was fortified with many hilltop fortresses sited not only topographically in connection to mineral ore, but also peripherally, to control both mining activity and access to the area's basin (Figure 5). The fortification of the Campigliese district suggests Populonia's need to protect the local mineral deposits against possible enemy incursions. Looking at the historical events known for this period, we can presume that the hilltop fortresses were built after the Alalia naval battle (540 BC) fought between the Etruscan/Carthaginian alliance and the Greek Phocaean colonies of Alalia for control over the Northern Tyrrhenian Sea [23,47].

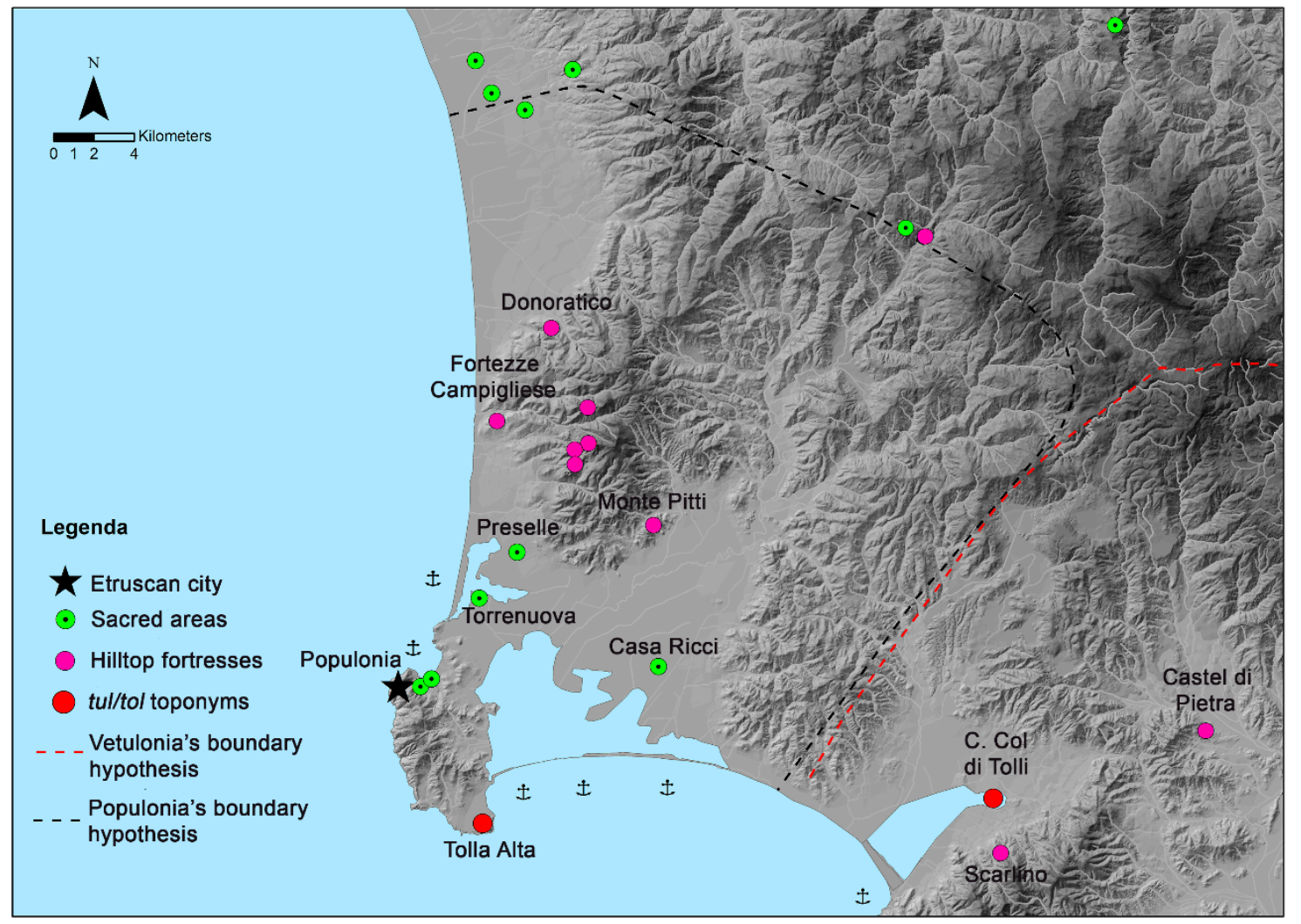

Figure 5. The distribution of the hilltop fortresses and the sacred areas of Populonia's territory in the 6th century BC.

From the 5th century BC, according to some accounts, Populonia's fortunes intertwined with the decline of Vetulonia and with the likely extension of Populonia's and Roselle's territories at the expense of the diminished city [48,49]. A closer look at the settlement arrangement of the Populonia territory highlights two facts that seem to support this hypothesis: (1) the establishment of the sacred area of Marsiliana [50,51], located along the route to the Massa Marittima ore deposits, might suggest the Populonia takeover of this mineral district [23]; and (2) the planning of a strategic fortification system that involved both the Italian peninsula and the Island of Elba: in the case of the mainland, some hilltop fortresses were sited on its territorial borders [26,52,53] (Figure 6). 


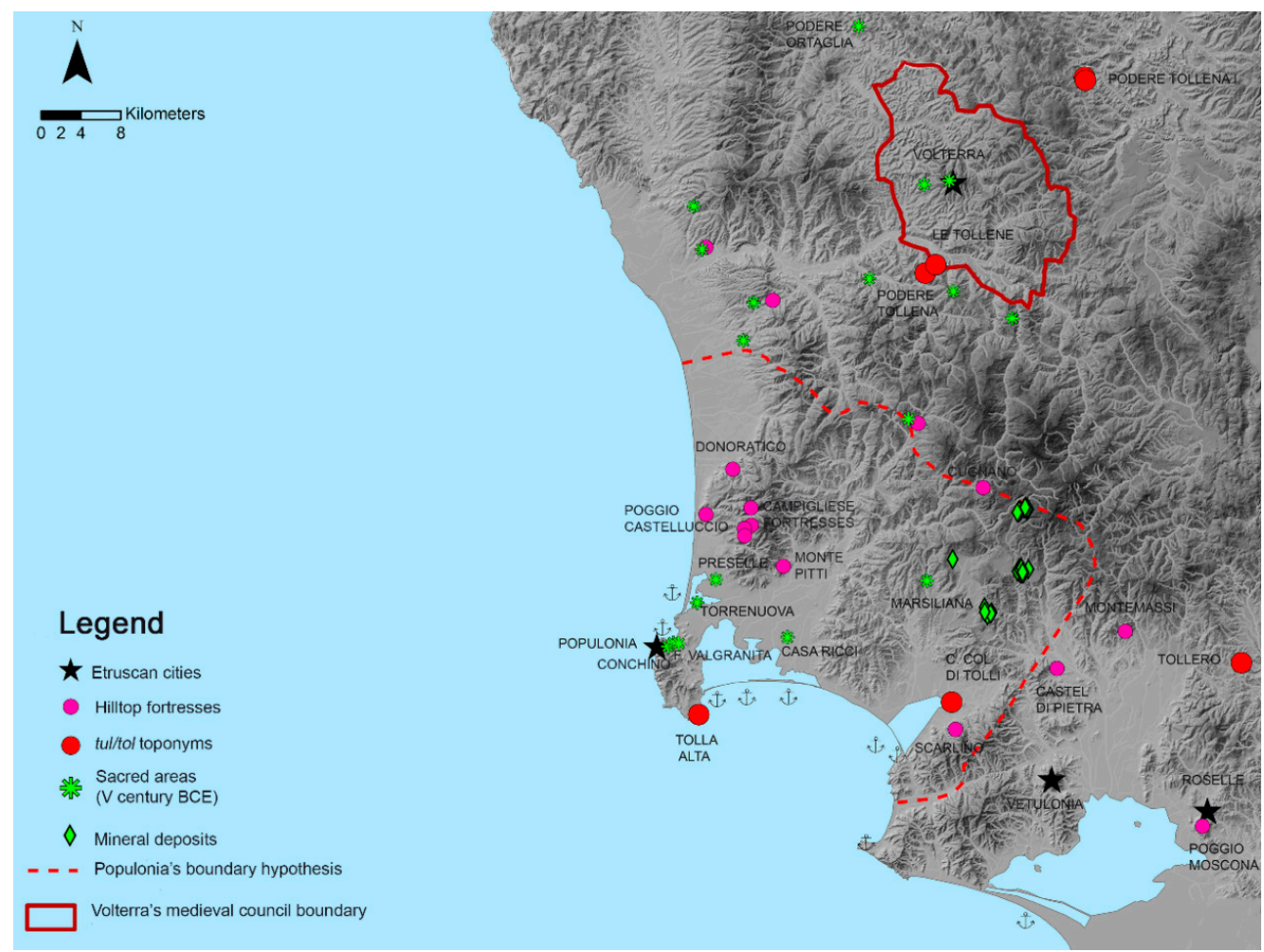

Figure 6. GIS general map of Populonia's sacred areas and hilltop fortresses distribution during the 5th century BC.

Populonia implemented the remarkable hilltop fortress system during the late 4th and early 3rd centuries BC, when the pronounced Roman interest in Northern Etruria's territories, particularly in the period between 311-283/282 BC, provided the foundation for the development of fortified hilltop settlements in Populonia's territory [26,52,53] (Figure 7).

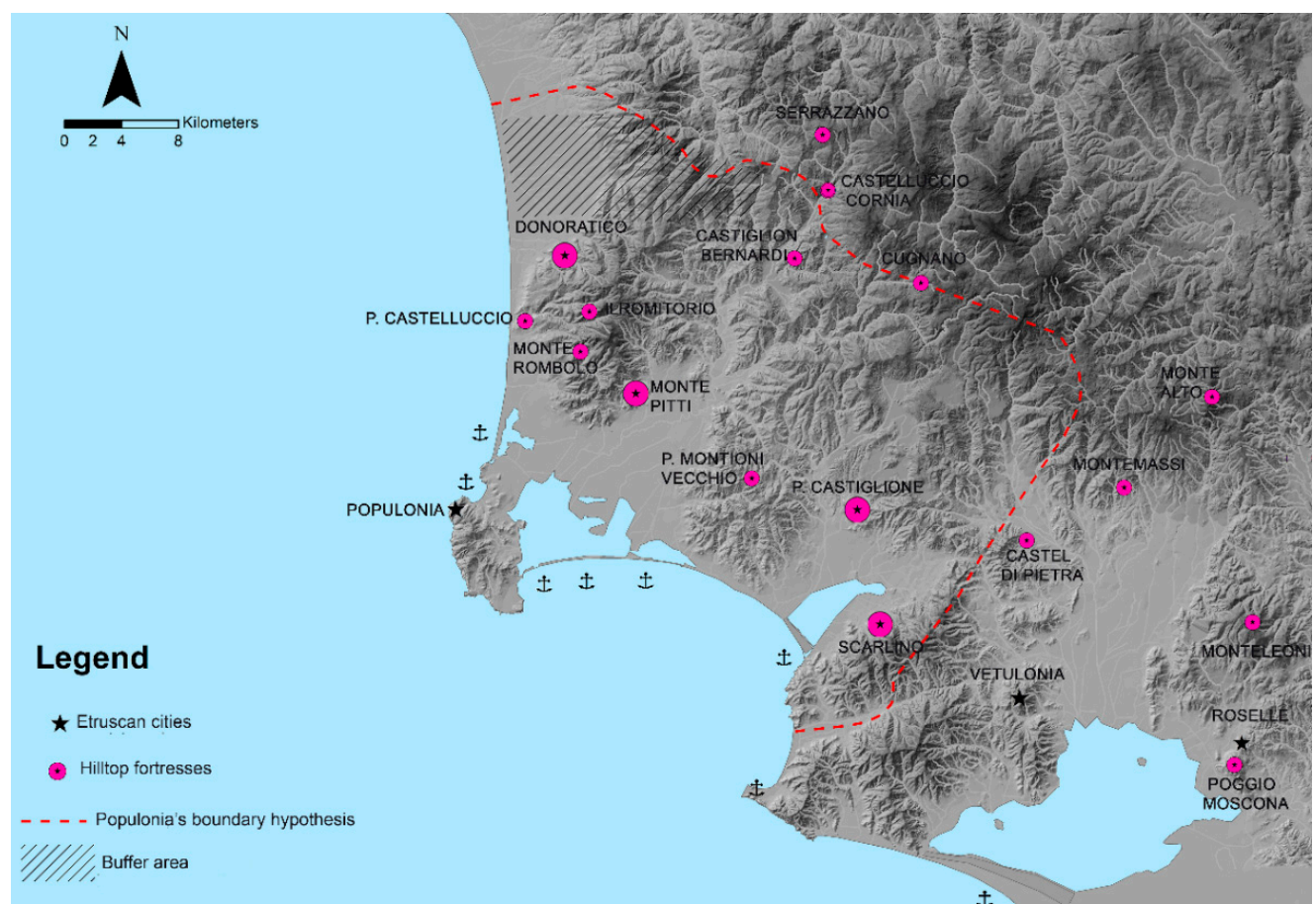

Figure 7. GIS general map of Populonia's hilltop fortresses distribution during the Hellenistic period. 
The chronological sequence of events mentioned by Livy corresponds to diagnostic pottery and material finds discovered during archaeological excavations undertaken in a number of Populonia's hilltop fortresses. Considering the lack of a specific denomination in classical terminology, the term "hilltop fortress" allows us to contextualize the Island of Elba's archaeological structures within an architectural and structural category. An examination of texts by classical authors provides some terms we might adopt to describe the archaeological evidence found on the Island of Elba, such as

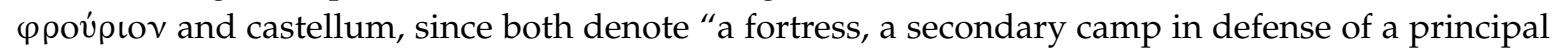
one or a strategic site, even a warehouse." This type of site arose in response either to an imminent military threat or to various phases of imperial expansion and the position was often abandoned after such threats had passed $[26,52,53]$. Before analyzing the characteristics of these settlements, we must examine the two factors that affect the topic of Populonia castella: (1) the majority of hilltop fortresses are known only through archaeological surveys; and (2) the medieval castles' overlapping of Etruscan bastions [23,47]. On this basis, we can offer some hypotheses concerning the settlement structures and their role within the defensive system. In light of the archaeological data, it is possible to note a number of main features shared by these fortified settlements. First, they are located on a cleared hilltop in a strategic position, providing control over travel routes; mineral, agricultural, and maritime resources; and crossroads. They were also surrounded by stonewalls for additional defense. These settlements were rectangular in plan, presumably to rectify the peak outlines and to bestow a quadrangular plan. Their construction technique, for the most part, involved the placement of rough-cut stones arranged in irregular rows; the walls were also endowed with a brick base and a clay court elevation. Inside the defensive walls, the buildings, about one hectare in area or less, were well structured. All of the fortresses were furnished with tanks for water conservation and areas for storing other supplies; the houses were made with clay elevations and covered by a tiled roof supported on a timber frame [52,53].

Set apart from each other at regular intervals of $9-10 \mathrm{~km}$, the fortresses on the peninsula created a sort of defensive ring placed some distance inland from the coastline. In this way, the fortresses, either individually or in sets of two, could control a specific area or resource. As we can see through the ArcGIS viewshed analysis, their sphere of influence included direct control over the Colline Metallifere mineral deposits $[52,53]$. The pottery record of the majority of the castella shows strong analogies to Populonia ceramics. On the basis of archaeological evidence, the local products generally seemed to prevail over imported goods. On this subject, we must mention a small group of tombs related to the Monte Pitti fortress. Here the grave artifacts are quite significant and include imported fine pottery and jewelry [54]. It is evident that Populonia created a hierarchical fortified system. On the mainland, the sites that can be considered at the top of the hierarchy, especially in terms of strategic importance, include Donoratico, Monte Pitti, Poggio Castiglione, and Scarlino. On the Island of Elba, on the contrary, the defensive network was characterized by two hilltop fortresses (Monte Castello and Castiglione San Martino) to which small-fortified settlements were linked. Finally, ArcGIS viewshed analysis indicates that all of the fortresses were in direct visual contact with each other. In addition, the results of the latter study serve both to question and increase our knowledge about the controversy concerning the supposed reconstructions of ancient boundaries between Populonia, Vetulonia, and Roselle. In fact, the viewshed analyses show that the castella of Poggio Castiglione and Scarlino were visually connected to Populonia and its territory. On the other hand, the fortresses of Castel di Pietra and Montemassi have a reciprocal visual connection with Poggio di Moscona, which has recently been numbered among the $\varphi$ pov́ $\rho\llcorner\alpha$ in the territory of Roselle. These hilltop fortresses were only abandoned between the mid-second and first centuries BC after imminent military threats in the region had diminished and the area as a whole was slowly Romanized [26,52,53].

It is reasonable to consider Populonia's strategically placed hilltop fortresses as a reaction to danger and threat and, simultaneously, as the outcome of surplus wealth, which would certainly have been required to realize the fortified settlement systems. Thus, we can imagine that the Classical and the Hellenistic landscape both on the mainland of Populonia and on the Island of Elba had assumed 
particular features as a "landscape of prosperity and of worry" [23,47].The central place is again concentrated on the Populonia acropolis which, endowed with an upper wall, became the main focus of the fortified settlements and the stronghold of the territorial defense. Its strategic position allowed a reciprocal visual connection among most of the hilltop fortresses in the Campigliese district and on the Island of Elba [55] (Figure 8).

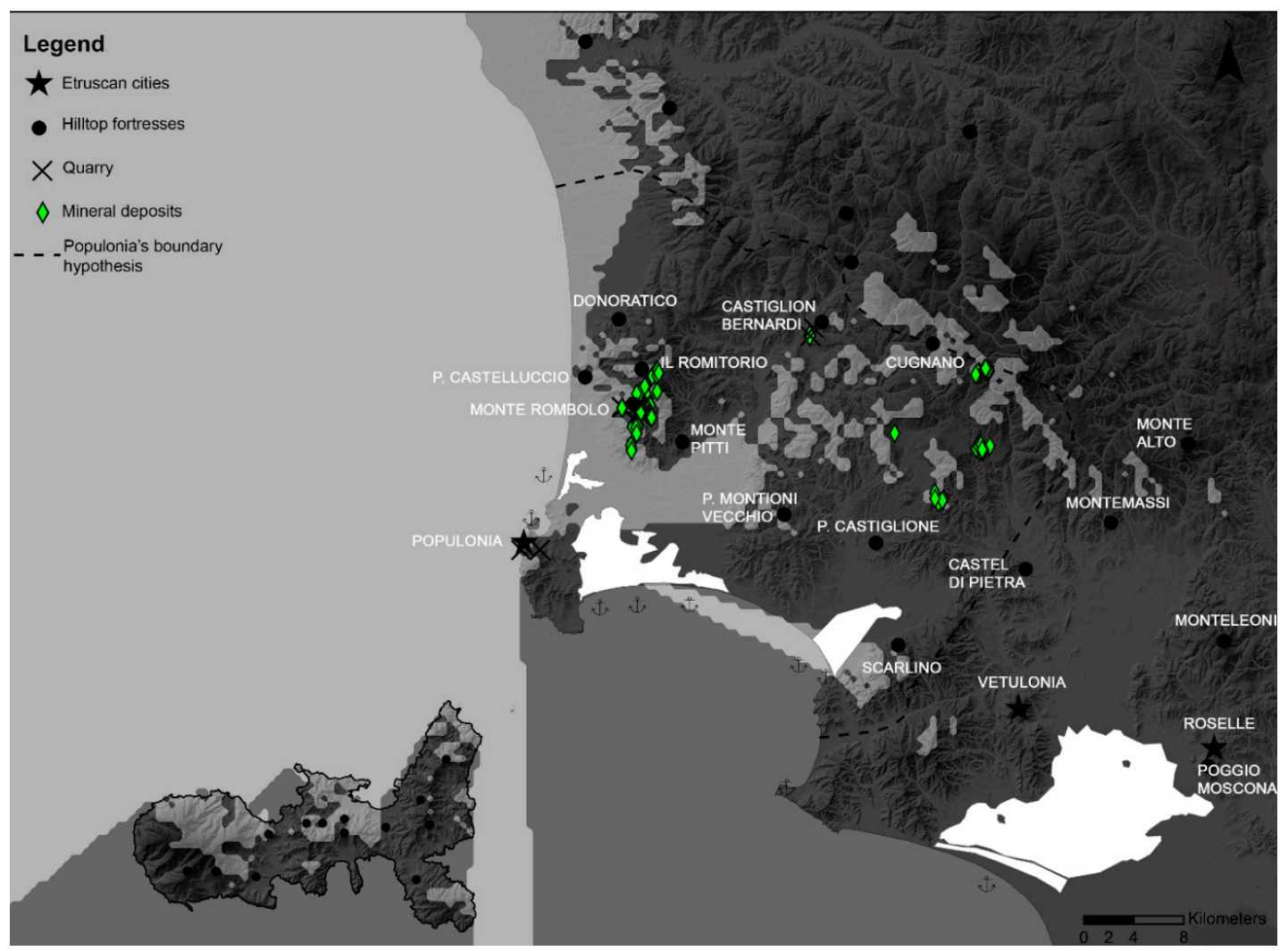

Figure 8. GIS viewshed analysis map from Populonia.

\section{A "Liminal Landscape" in the Territory of Populonia}

The term "liminal" comes from the Latin word limen, which means border. The Concise Oxford English Dictionary defines liminal as an adjective relating to a transitional or initial stage or at a boundary or threshold [56]. Thus, there are different meanings and connotations linked to this word. Arnold van Gennep was the first scholar who used the term "liminal" in his analyses of rituals. Within transitional rites, he distinguishes three categories of rites-preliminary, liminal and postliminal—connecting each one to a different stage in human life. In the second chapter of The Rites of Passage, he discusses territorial passage, analyzing the rituals used when entering the neutral grounds between marked territories [57]. Van Gennep's ideas were further investigated by the social anthropologist Victor Turner, who concentrated on the liminal phase of initiation rituals, with particular attention to related social and symbolical aspects [58].

"Liminal landscapes" are geographical areas set in rougher topographic environments such as mountains, forests, heathlands, wetlands, coastal areas and arctic zones. [59]. To inhabit a liminal landscape has frequently implied the need to adopt particular ways, structures and routines of living. Basically these different results consist of: house construction using raw perishable materials, land reclamation work, flow regulation work and terracing [60] (p. 9). Liminal landscapes are often associated with nature and the relative wilderness lying beyond cultivated spheres. Such associations have contributed to the downgrading of liminal landscapes' historical, cultural and social importance in society. Moreover, these outlying areas are generally considered passive (as compared to an 
active center) and are thus judged to be marginal also from a social perspective. From the local inhabitants' viewpoint, the same landscapes, even when they are hardly marginal, are central in terms of subsistence strategies for the local people. The marginal landscapes of today were not necessarily the marginal landscapes of the earlier times [59]. Thus, the concept of "liminal" becomes an issue between relative points of view. Some archaeologists are currently working on the intensive exchange connections and tight cultural material proximity existing between central or hegemonic areas and marginal or subordinate zones. In a new perspective, we can see new connectivity trajectories not only between different cultural geographic areas but also among elements that traditional viewpoints considered opposite, i.e., fortified cities and countryside vs. eschatia, Roman century vs. saltus, citizens and peasants vs. pastores [60] (p. 6). Thanks to the influence of P. Horden and N. Purcell's book, The Corrupting Sea [61], a new understanding of marginal categories is one of the most important advances in Mediterranean landscape archaeology research in recent years.

With this premise, there is an example of "liminal landscape" that, for several reasons, can be distinguished in a specific area located in the northeastern stretch of territory between Populonia and Volterra. At first, it was demarcated by specific morphological features, such as hills, woods, water (especially in the form of hot and cold sulphur springs), and geothermal phenomena [62] (Figure 9). The liminal aspect of this area appears to have been understood by the ancients who, cognizant of "natural forces", introduced specific sanctuaries and sacred areas; these included the Hellenistic and Roman complex devoted to the cult of Minerva and Silvano in the Sasso Pisano area [63] (Figure 10), and the Roman cult of Bellona in the Monteverdi Marittimo district, which in all likelihood was preceded by a Hellenistic equivalent $[23,46]$. These cults were significantly linked to woods, water and the wilderness, and were probably also tied to ancient pastoral activities. The archaeological evidence for these practices is very difficult to detect today. Although the lack of archaeological evidence urges us towards a cautious approach, we might be able to re-evaluate the role of this peripheral district and its close relationship with the central place. Starting approximately from the 6th century BC, Populonia began to extend its influence on the Monterotondo area, located on the borders of its territory [64,65]. This expansion might not be a coincidence since, among the various reasons, we can recall Populonia's need for wood resources to support its intensive metallurgical activities [66,67].

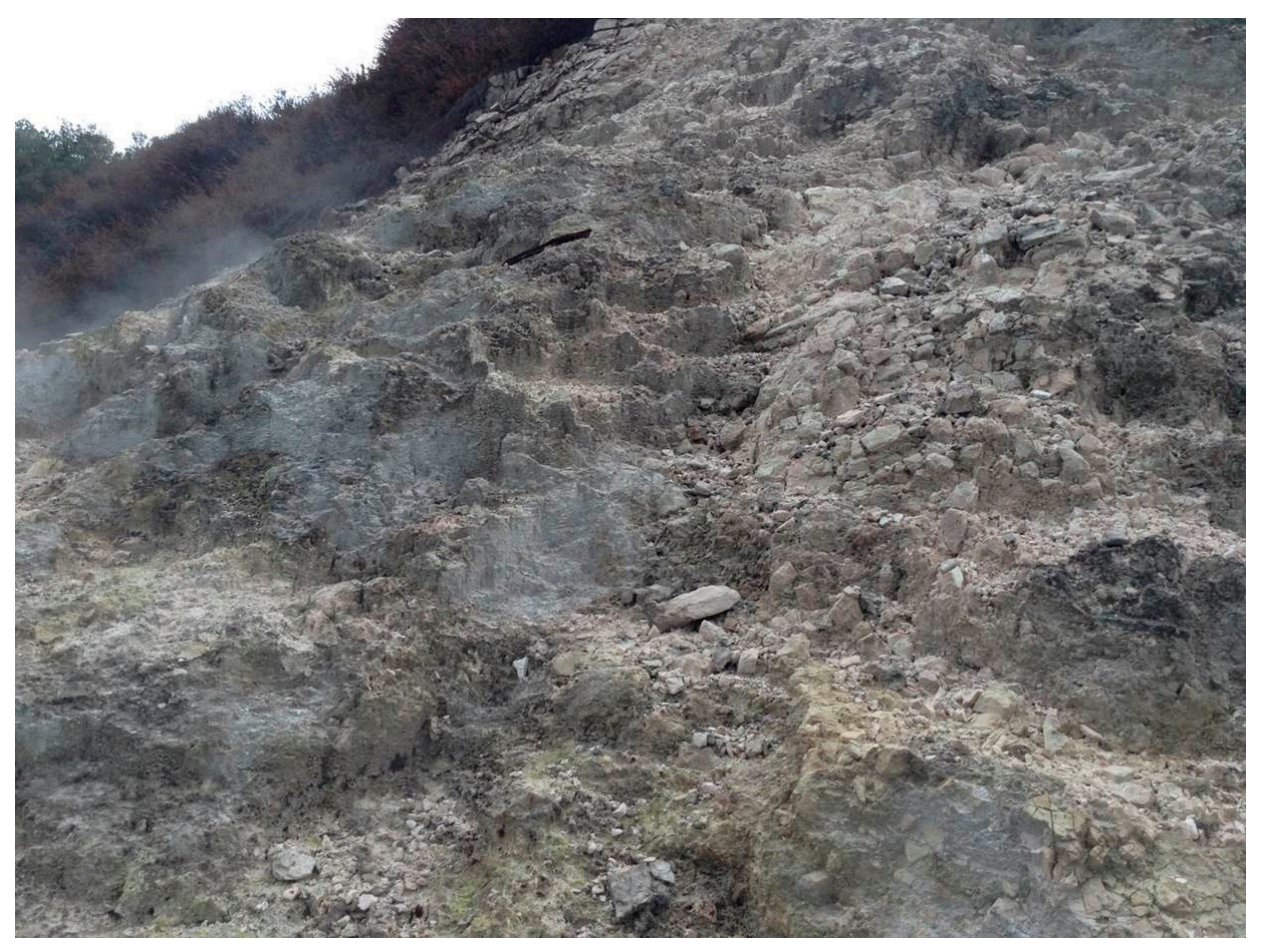

Figure 9. An example of the geothermal phenomena in the Sasso Pisano area. 


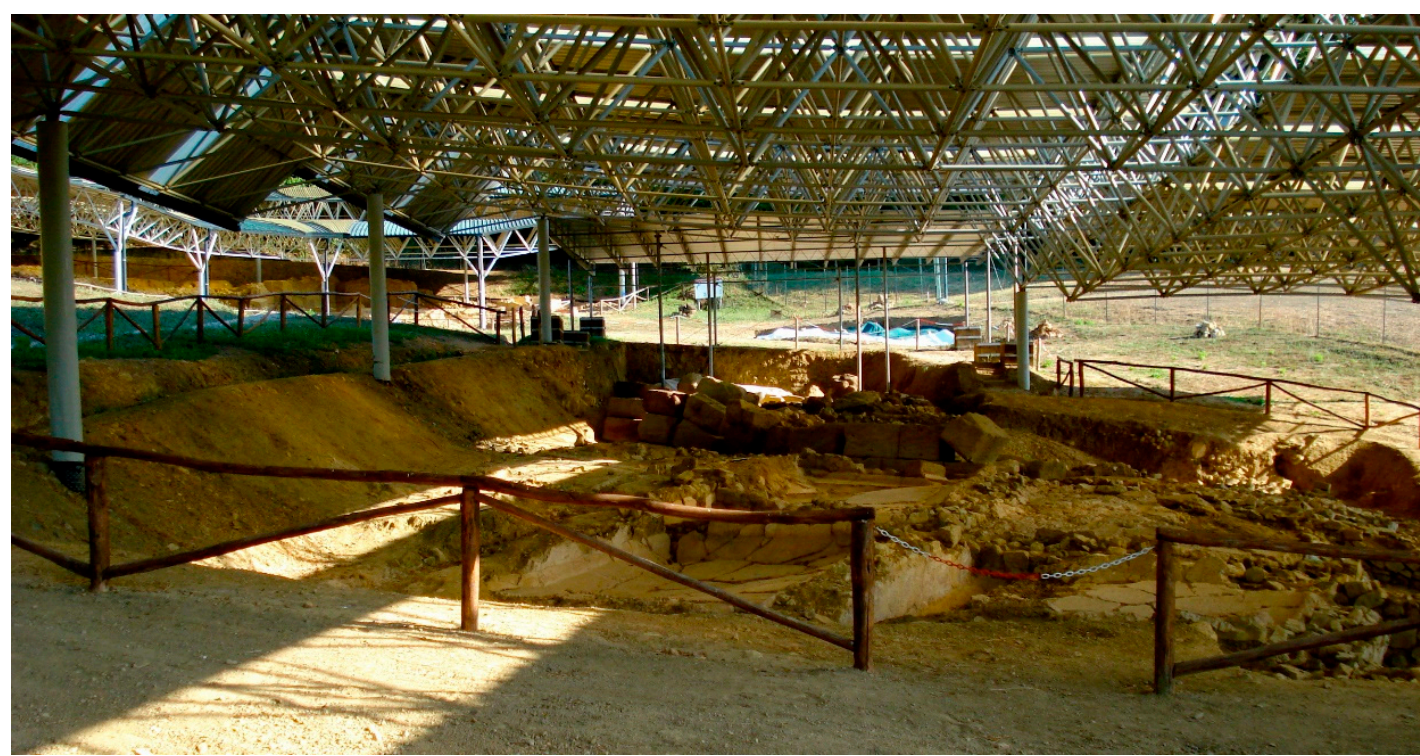

Figure 10. The Sacred thermal complex in the Sasso Pisano area, known as the Il Bagnone archaeological area.

The exploitation of this particular district and its natural resources also continued during the Classical and Hellenistic periods [64,65]. As a result of increased Roman pressure, Populonia might have reinforced its control over this area by building the boundary hilltop fortress of Castiglion Bernardi $[26,52,53]$ (Figure 11).

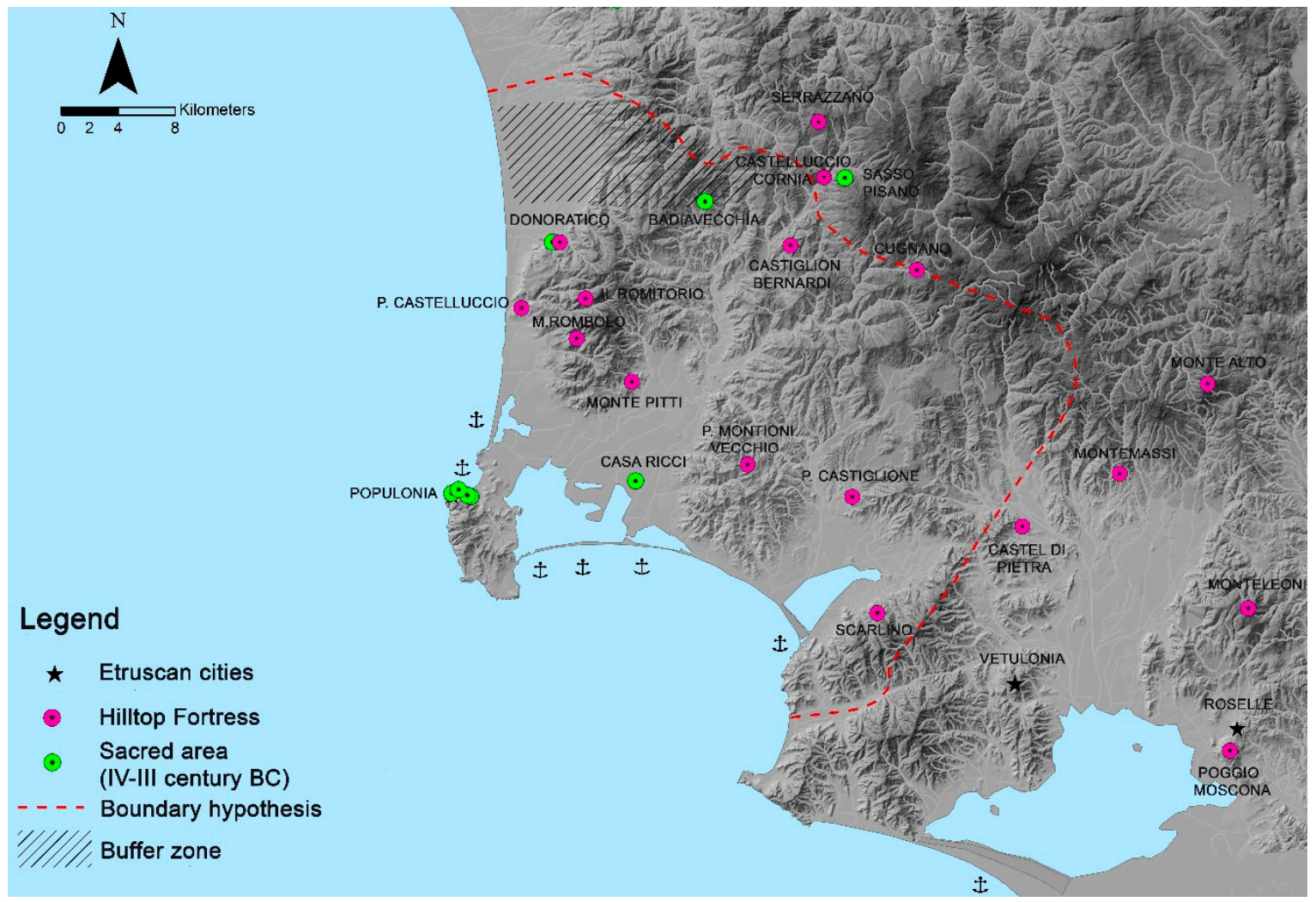

Figure 11. GIS general map of Populonia's sacred areas and hilltop fortresse distribution during the Hellenistic period. The northeastern stretch of territory between Populonia and Volterra. 


\section{Conclusions}

This article aims to outline my new data on the urbanization of Populonia starting from its foundation, with particular reference to the results of archaeological surveys carried out by the University of Siena since the 1980s. The landscape archaeology approach has allowed us to reconstruct the Etruscan city's organization of settlements as well as its management of resources. In addition, this investigative tool has proven the most effective method to detect both places of economic or ideological centrality and specific liminal landscapes in the territory of Populonia. Our research leads us to suggest-in spite of several anomalies in the urban development process and unconventional choices in the control of Populonia's territory-that the Etruscan city's acropolis seems to have played the role of central place starting right from the establishment of the city. A hierarchical settlement system, based on a network of sites and the foundation of new population centers, was promoted starting from the end of the 9th-the beginning of the 8th century BC. Once the city ended its development process and, especially, in the Hellenistic period, policies such as the hierarchical settlement system in the chora and supply basin exploitation were mainly implemented through the foundation of hilltop fortresses both on the mainland and on the Island of Elba. The central place was again concentrated on the Populonia acropolis which, endowed with an upper wall, became the main focus of the fortified settlements and the stronghold of the defence against Roman imperialism. Within some of the new acquisitions coming from my PhD research we have to consider the feature of the hilltop fortresses system and the detection of a "liminal landscape" in the northeastern stretch of the territory between Populonia and Volterra. This particular part of the landscape had been a sacred district with a strong peripheral character and possibly close connections to the central place thanks to the significant availability of natural resources.

Funding: This research received no external funding.

Acknowledgments: I would like to thank Franco Cambi, my tutor, Maria Luisa Marchi, Andrea Zifferero, Simon Stoddart, my co-tutors, and to Giuliano Volpe for having supported me during my PhD research project. A special thank goes to the "Soprintendenza per i Beni Archeologici della Toscana" for the administrative and technical supports. My PhD research has benefited greatly from discussion with Cynthia Mascione, Matteo Milletti, Elisabetta Ponta and Luisa Dallai. I am also grateful to Daniele Manacorda, Gabriele Cifani and Maria Grazia Granino for their suggestions and availability. Last but not least, my thanks go to Giorgos Papantoniou and Athanasios Vionis who encourage me to write down this paper.

Conflicts of Interest: The author declares no conflict of interest.

\section{References}

1. Cifani, G. Storia di una Frontiera. Dinamiche Territoriali e Gruppi Etnici Nella Media Valle Tiberina dalla Prima età del Ferro alla Conquista Romana; Istituto Poligrafico e Zecca dello Stato: Roma, Italy, 2003; p. 23. (In Italian)

2. Turner, F.J. The Frontier in American History; H. Holt and Company: New York, NY, USA, 1945.

3. Lattimore, O. Studies in Frontier History. Collected Papers; Oxford University Press: London, UK, 1962.

4. Wallerstein, I. The Modern World-System; Academic Press: New York, NY, USA, 1974; Volume 1.

5. Sherratt, A. What Would a Bronze-Age World System Look Like? Relations between Temperate Europe and the Mediterranean in Later Prehistory. J. Eur. Archaeol. 1993, 1, 1-57. [CrossRef]

6. Sherratt, A. 'Who are you Calling Peripheral?' Dependence and Independence in European Prehistory. In Trade and Exchange in Prehistoric Europe; Scarre, C., Healy, F., Eds.; Oxbow Monograph 33; Oxbow Books: Oxford, UK, 1993; pp. 245-255.

7. Sherratt, A. Core, Periphery and Margin: Perspectives on the Bronze Age. In Development and Decline in the Mediterranean Bronze Age; Mathers, C., Stoddart, S., Eds.; J.R. Collis Publications: Sheffield, UK, 1994; pp. 335-345.

8. Donnan, H.; Wilson, T. Borders: Frontiers of Identity, Nation and State; Berg Publishers: Oxford, UK, 1999.

9. Green, S.F. Notes from the Balkans. Locating Marginality and Ambiguity on the Greek-Albanian Border; Princeton University Press: Princeton, NJ, USA, 2005. 
10. Cifani, G.; Ceccarelli, L.; Stoddart, S. Exploring a frontier area in Etruria: The Civita di Grotte di Castro survey. In Landscape, Ethnicity and Identity in the Archaic Mediterranean Area; Cifani, G., Stoddart, S., Eds.; Oxbow Books: Oxford, UK, 2012; pp. 163-170.

11. Clarke, D.L. Spatial Information in Archaeology. In Spatial Archeology; Academic Press: London, UK; New York, NY, USA; San Francisco, CA, USA, 1977; pp. 1-32.

12. Renfrew, A.C. Trade as Action at a Distance: Questions of Integration and Communication. In Ancient Civilisation and Trade; Sabloff, J.A., Lamberg-Karlovsky, C.C., Eds.; University of New Mexico Press: Albuquerque, NM, USA, 1975; pp. 3-59.

13. Redhouse, D.I.; Stoddart, S.K.F. Mapping Etruscan State Formation. In State Formation in Italy and Greece; Terrenato, N.D., Haggis, C., Eds.; Questioning the Neoevolutionist Paradigm: Oxford, UK, 2010; pp. 164-180.

14. Renfrew, A.C.; Cherry, J.F. Peer Polity Interaction and Socio-Political Change; Cambridge University Press: Cambridge, UK, 1986.

15. Renfrew, A.C. Approaches to Social Archaeology; Edinburgh University Press: Edinburgh, UK, 1984.

16. De Guio, A. Potere, archeologia del (s. v.). In Dizionario di Archeologia. Temi, Concetti e Metodi; Francovich, R., Manacorda, D., Eds.; Laterza Editori: Roma/Bari, Italy, 2000; pp. 222-228. (In Italian)

17. Veronese, F. Lo Spazio e la Dimensione del Sacro. Santuari Greci e Territorio Nella Sicilia Arcaica; Esedra Editrice: Padova, Italy, 2006. (In Italian)

18. Bender, B. (Ed.) Landscape: Politics and Perspective; Berg: Oxford, UK, 1993; p. 3.

19. Ashmore, W. Social archaeologies of landscape. In A Companion to Social Archaeology; Meskell, L., Preucel, R.W., Eds.; Blackwell: Oxford, UK, 2004; pp. 255-266.

20. Papantoniou, G.; Vionis, A.K. Landscape Archaeology and Sacred Space in the Eastern Mediterranean: A Glimpse from Cyprus. Land 2017, 6, 40. [CrossRef]

21. Knapp, A.B.; Ashmore, W. Archaeological landscapes: Constructed, conceptualized, ideational. In Archaeologies of Landscape: Contemporary Perspectives; Ashmore, W., Knapp, A.B., Eds.; Blackwell: Oxford, UK, 1999; pp. 1-30.

22. Milletti, M. La nascita di Populonia: Dati e ipotesi sullo sviluppo della città etrusca all'alba del primo millennio a.C. In Le Città Visibili: Archeologia dei Processi di Formazione Urbana. I, Proceedings of the Penisola Italiana e Sardegna, Atti del Seminario Internazionale in onore di Gilda Bartoloni, Alberto Moravetti, Alghero, Italy, 31 January-1 February 2014; Moravetti, A., Bartoloni, G., Rendeli, M., Eds.; Officina Edizioni: Roma, Italy, 2015; pp. 59-96. (In Italian)

23. Di Paola, G. Territorializzazione e Bacini di Approvvigionamento in Etruria. Frontiera, Ferro e Fortezza d'altura a Populonia. Ph.D. Thesis, University of Foggia, Foggia, Italy, 25 June 2015. (In Italian)

24. Isola, C. Le lagune di Populonia dall'antichità alle bonifiche. In Materiali da Costruzione e Produzione del Ferro. Studi Sull'economia Populoniese tra Periodo Etrusco e Romanizzazione; Cambi, F., Cavari, F., Mascione, C., Eds.; Edipuglia: Bari, Italy, 2009; pp. 163-170. (In Italian)

25. Giroldini, P. Fra la campagna e il mare. Sviluppo e contrazione del popolamento nella piana di Piombino dall'VIII al V secolo a. C. In La Corsica e Populonia, Proceedings of the Atti del XXVIII Convegno di Studi Etruschi ed Italici, Bastia, Aleria, France, Piombino, Populonia, Italy, 25-29 October 2011; Bretschneider, G., Ed.; Giorgio Bretschneider Editore: Pisa-Roma, Italy, 2015; Volume 28, pp. 535-552. (In Italian)

26. Cambi, F.; Di Paola, G.; Pagliantini, L. Populonia, E. Identità etniche, bacini di approvvigionamento e scambi fra terraferma e isole. Un esperimento di territorializzazione. In Storia e Archeologia Globale 2. I Pascoli, $i$ Campi, il Mare. Paesaggi D'altura e di Pianura in Italia Dall'età del Bronzo al Medioevo; Cambi, F., De Venuto, G., Goffredo, R., Eds.; Edipuglia: Bari, Italy, 2015; pp. 73-91, ISBN 978-88-7228-775-0. (In Italian)

27. Cambi, F. I Romani nel Tirreno Settentrionale. Paesaggi di terra e di mare fra Populonia e l'Arcipelago Toscano. In Paesaggi Mediterranei di età Romana. Archeologia, Tutela, Comunicazione; Mastrocinque, G., Ed.; Edipuglia: Bari, Italy, 2017; pp. 111-124. (In Italian)

28. Falchi, P.; Milletti, M. Sardegna ed Etruria tra la fine dell'età del Bronzo e la prima età del Ferro: Importazioni e fenomeni di acculturazione. In Proceedings of the Atti della XLIV Riunione Scientifica, La Preistoria e la Protostoria della Sardegna, Cagliari, Barumini, Sassari, Italy, 23-28 November 2009; Volume IV-Posters. Nuove Grafiche Puddu: Ortacesus, Italy, 2012; pp. 1613-1617. (In Italian)

29. Falchi, P. Le faretrine. In Gli Etruschi e la Sardegna. Tra la Fine dell'età del Bronzo e gli Inizi dell'età del Ferro, Catalogo della Mostra (Museo del Territorio di Sa Corna Arrubia 2008); Lo Schiavo, F., Miletti, M., Falchi, P., Eds.; Contemporanea Edizioni: Cagliari, Italy, 2008; pp. 41-47. (In Italian)

30. Bartoloni, G. Le Società dell'Italia Primitiva; Carocci Editore: Roma, Italy, 2003. (In Italian) 
31. Cygielman, M.; Lo Schiavo, F.; Milletti, M.; Pagnini, L. Populonia a Vetulonia fra Corsica e Sardegna, con appendice di Nicolas Garnier. In La Corsica e Populonia, Proceedings of the Atti del XXVIII Convegno di Studi Etruschi ed Italici, Bastia, Aleria, France, Piombino, Populonia, Italy, 25-29 October 2011; Bretschneider, G., Ed.; Giorgio Bretschneider Editore: Pisa-Roma, Italy, 2015; Volume 28, pp. 273-315. (In Italian)

32. Bartoloni, G. Populonium etruscorum quodam hoc tantum in litore. Aspetti e caratteri di una comunità costiera della prima età del Ferro. Archeologia Classica 1991, 43, 1-37. (In Italian)

33. Carter, J.C. La Scoperta del Territorio Rurale Greco di Metaponto; Osanna Edizioni: Venosa, Italy, 2008. (In Italian)

34. Fedeli, F. La necropoli protovillanoviana di Villa del Barone (Piombino, LI). I. I materiali. In Rassegna di Archeologia Piombinese; 21A, (2004-2005); All'Insegna del Giglio: Florence, Italy, 2005. (In Italian)

35. Fedeli, F. Nuovo insediamento protostorico sul litorale di San Vincenzo (LI). In Rassegna di Archeologia 12(1994-1995); All'Insegna del Giglio: Florence, Italy, 2005; pp. 235-250. (In Italian)

36. Zanini, A. Dal Bronzo al Ferro. Il II Millennio a. C. nella Toscana Centro-Occidentale; Pacini Editore: Pisa, Italy, 1997; pp. 123-126. (In Italian)

37. Baratti, G. Un sito per la produzione del sale sulla spiaggia di Baratti (area centro Velico) alla fine dell'Età del Bronzo. In Materiali per Populonia 9; Baratti, G., Fabiani, F., Eds.; Edizioni ETS: Pisa, Italy, 2010; pp. $243-260$. (In Italian)

38. Fedeli, F. Ricerche pre-protostoriche nel territorio di San Carlo (San Vincenzo, LI). I materiali di Vallin del Mandorlo. In Rassegna di Archeologia 12, (1994-1995); All'Insegna del Giglio: Florence, Italy, 1996; pp. 149-234. (In Italian)

39. Acconcia, V.; Milletti, M.; Pitzalis, F.A. Poggio del Telegrafo: Le ricerche nell'abitato degli anni 2003-2004. In Scienze dell'Antichità, 12 (2004-2005); Scienze e Lettere: Roma, Italy, 2007; pp. 57-87. (In Italian)

40. Acconcia, V.; Milletti, M. Pratiche metallurgiche e circolazione dei saperi all'origine di Populonia. In Materiali da Costruzione e Produzione del Ferro. Studi Sull'economia Populoniese fra Periodo Etrusco e Romanizzazione; Cambi, F., Cavari, F., Mascione, C., Eds.; Edipuglia: Bari, Italy, 2009; pp. 141-148. (In Italian)

41. Marino, T. Aspetti e fasi del processo formativo delle città in Etruria meridionale costiera. In Le Città Visibili: Archeologia dei Processi di Formazione Urbana. I, Proceedings of the Penisola Italiana e Sardegna, Atti del Seminario Internazionale in onore di Gilda Bartoloni, Alberto Moravetti, Alghero, Italy, 31 January-1 February 2014; Moravetti, A., Bartoloni, G., Rendeli, M., Eds.; Officina Edizioni: Roma, Italy, 2015; pp. 97-141. (In Italian)

42. Zifferero, A. Attività minerarie e trasferimento dei saperi metallurgici nell'alto Tirreno: Conoscenze attuali e prospettive di ricerca. In Materiali da Costruzione e Produzione del Ferro. Studi Sull'economia Populoniese fra Periodo Etrusco e Romanizzazione; Cambi, F., Cavari, F., Mascione, C., Eds.; Edipuglia: Bari, Italy, 2009; pp. 149-158. (In Italian)

43. Bonamici, M. Nuove Ricerche Nell'area Degli Edifici Industriali di Populonia; AGOGE; Università di Pisa: Pisa, Italy, 2007; Volume 3, pp. 255-265. (In Italian)

44. Maggiani, A. Le iscrizioni di età tardo-classica ed ellenistica. In Populonia in età Ellenistica: I Materiali dalle Necropoli (Atti del Seminario, 1986); Romualdi, A., Ed.; Il Torchio: Firenze, Italy, 1992; pp. 183-184. (In Italian)

45. Zifferero, A. Confini e luoghi di culto nel suburbio e nell'agro populoniese. In Materiali per Populonia 5; Aprosio, M., Mascione, C., Eds.; Edizioni ETS: Pisa, Italy, 2005; pp. 391-427. (In Italian)

46. Di Paola, G.; Vanni, E. Paesaggi sacri di frontiera e mobilità: Alcuni spunti dall'Etruria settentrionale costiera. In Santuari Mediterranei tra Oriente ed Occidente. Interazioni e Contatti Culturali, Atti del Convegno Internazionale, Civitavecchia-Roma 2014; Russo Tagliente, A., Guarnieri, F., Eds.; Scienze e Lettere: Roma, Italy, 2016; pp. 93-104. (In Italian)

47. Di Paola, G. Populonia e il suo territorio: Strategie difensive, risorse. Trasformazioni del paesaggio. Manuscript in preparation. Unpublished work; Submitted. (In Italian)

48. Cygielman, M. Per una definizione di città nell'Etruria settentrionale: Il caso di Vetulonia. In Città e Territorio in Etruria. Per una Definizione di Città nell'Etruria Settentrionale; Manganelli, M., Pacchiani, E., Eds.; Grafiche Boccacci: Colle di Val d'Elsa, Italy, 2002; pp. 161-187. (In Italian)

49. Camporeale, G. Vetulonia. In Gli Etruschi delle Città. Fonti, Ricerche e Scavi; Bruni, S., Ed.; Silvana Editore: Milano, Italy, 2010; pp. 124-131. (In Italian)

50. Monaco, G. Museo Civico, Collezioni Archeologiche; Soc. Tip. Barbieri, Noccioli: Empoli, Italy, $1964 ;$ p. 9. (In Italian)

51. Paribeni Rovai, E. L'area di Poggio Castiglione e altre località minori. In Museo Archeologico Massa Marittima; Octavo: Firenze, Italy, 1993; pp. 50-57. (In Italian) 
52. Cambi, F.; Di Paola, G. Etruscan Strategies of Defense: Late Classical and Early Hellenistic Hilltop Fortresses in the Territory of Populonia. Etruscan Stud. 2013, 16, 190-209. [CrossRef]

53. Cambi, F.; Di Paola, G.; Pagliantini, L. Populonia e la romanizzazione dell'Etruria settentrionale. In Scienze dell'Antichità 19. Mura di Legno, Mura di Terra, Mura di Pietra: Fortificazioni nel Mediterraneo Antico, Proceedings of the Atti del Convegno Internazionale Università La Sapienza di Roma, Roma, Italy, 7-9 May 2012; Bartoloni, G., Michetti, L., Eds.; Quasar Edizioni: Roma, Italy, 2013; pp. 387-410. (In Italian)

54. Bruni, S.; Fedeli, F.; Romualdi, A.; Sheperd, E.J. Montepitti-materiali. In Isidoro Falchi. Un Medico al Servizio dell'archeologia. Un Protagonista della Ricerca Italiana di Fine Ottocento; Bruni, S., Ed.; Catalogo della Mostra; Montopoli Valdarno 1995; Bandecchi \& Vivaldi: Pontedera, Italy, 1995; pp. 197-222. (In Italian)

55. Mascione, C.; Salerno, S. Il sistema difensivo di Populonia: Nuovi dati sulle mura dell'Acropoli. In Scienze dell'Antichità 19. Mura di Legno, Mura di terra, Mura di Pietra: Fortificazioni nel Mediterraneo Antico, Proceedings of the Atti del Convegno Internazionale Università La Sapienza di Roma, Roma, Italy, 7-9 May 2012; Bartoloni, G., Michetti, L., Eds.; Quasar Edizioni: Roma, Italy, 2013; pp. 411-427. (In Italian)

56. Soanes, C.; Stevenson, A. Liminal, the Concise Oxford English Dictionary, 11 Revised; Oxford University Press: Chicago, IL, USA, 2006.

57. Van Gennep, A. The Rites of Passage; Translated by Vizedom, M.B. and Caffee, G.L., Introducing by Kimball, S.T.; Chicago University Press: Chicago, IL, USA, 1960.

58. Turner, V. Betwixt and Between: The Liminal Period in Rites de Passage. In Man Makes Sense; Hammel, E.A., Simmons, W.S., Eds.; Little, Brown \& Co.: Boston, MA, USA, 1970.

59. Holm, I.; Stene, K.; Svensson, E. Liminal Landscapes-A brief Overview. In Liminal Landscapes. beyond the Concepts of 'Marginality' and 'Periphery'; Holm, I., Stene, K., Svensson, E., Eds.; Oslo Academic Press and Institute for Archaeology, Conservation and History, University of Oslo: Oslo, Norway, 2009; pp. 5-9.

60. Cambi, F.; De Venuto, G.; Goffredo, F. Introduzione. Riconnettere i paesaggi, integrare la marginalità. In Storia e Archeologia Globale 2. I Pascoli, i Campi, il mare. Paesaggi D'altura e di Pianura in Italia dall'età del Bronzo al Medioevo; Cambi, F., De Venuto, G., Goffredo, R., Eds.; Edipuglia: Bari, Italy, 2015; pp. 5-11. (In Italian)

61. Horden, P.; Purcell, N. The Corrupting Sea. A Study of Mediterranean History; Blackwell: Oxford, UK, 2000.

62. Manacorda, D. Spigolature epigrafiche. Un'iscrizione paleocristiana, S. Regolo e i santuari di confine. In Materiali per Populonia 7; Acconcia, V., Rizzitelli, C., Eds.; Edizioni ETS: Pisa, Italy, 2008; pp. 305-321. (In Italian)

63. Esposito, A.M. Castelnuovo Val di Cecina (PI). Il complesso sacro-termale etrusco di Sasso Pisano. In Notiziario della Soprintendenza pei i beni Archeologici della Toscana; 1/2005; All'Insegna del Giglio: Firenze, Italy, 2005; pp. 224-232. (In Italian)

64. Ponta, E. Dinamiche di Formazione e Trasformazione del Paesaggio fra Tarda Antichità e Alto Medioevo. Il Caso di Monterotondo Marittimo (GR). Master's Thesis, University of Siena, Siena, Italy, 2011. (In Italian)

65. Ponta, E. Il paesaggio di Monterotondo Marittimo tra Antichità e Alto Medioevo. In Monterotondo Marittimo. Un Paese di Confine; Rotundo, F., Scapin, P., Eds.; Edizioni Effigi: Arcidosso, Italy, 2014; pp. 17-26. (In Italian)

66. Fiumi, E. L'utilizzazione dei Lagoni Boraciferi della Toscana Nell'industria Medievale; Carlo Cya Editore: Firenze, Italy, 1943. (In Italian)

67. Ponta, E. La viabilità romana fra Castiglione della Pescaia e Populonia. In Materiali per Populonia 5; Aprosio, M., Mascione, C., Eds.; Edizioni ETS: Pisa, Italy, 2006; pp. 453-468. (In Italian)

(c) 2018 by the author. Licensee MDPI, Basel, Switzerland. This article is an open access article distributed under the terms and conditions of the Creative Commons Attribution (CC BY) license (http:/ / creativecommons.org/licenses/by/4.0/). 